\title{
Perspectives
}

\section{Hematopoietic Growth Factors}

\author{
Colin A. Sieff \\ Division of Pediatric Oncology, Dana-Farber Cancer Institute, Boston, Massachusetts 02115
}

The process of blood cell formation, by which a small number of self-renewing stem cells give rise to lineage committed progenitor cells that subsequently proliferate and differentiate to produce the circulating mature blood cells, is sustained throughout life by a group of glycoprotein hormonal growth factors. These hormones are known collectively as the colony-stimulating factors (CSFs) ${ }^{1}$ (1); the term derives from the in vitro observation that the CSFs stimulate progenitor cells of different hematopoietic cell lineages to form discrete colonies of recognizable maturing cells. The different factors have been operationally defined by prefixes denoting the major type of colony produced, e.g., granulocyte macrophage CSF (GM-CSF). Not only is the presence of CSFs necessary for the proliferation of progenitor cells but these factors affect the function of mature cells as well (2-8); furthermore, they may be the major regulators of increased cell production during states of increased demand. It is not yet clear whether they play a pathogenetic role in some forms of leukemia.

During the past few years, the genes for five murine and human factors have been cloned, and recombinant forms of the proteins produced and purified. The recombinant CSFs have similar actions to their natural counterparts. The prospect of their availability in large quantities has provided the impetus for intensive investigation into their actions, to identify circumstances in which they may be therapeutically useful. The hematopoietic system with its regulators also serves as a paradigm for other systems with self-renewing stem cell populations sustaining the production of both short- and long-lived mature cells.

\section{Types of CSF}

Recent data on the biological activities of several highly purified recombinant hormones have led to the appreciation that the existing nomenclature is inadequate. For example, although human GM-CSF was initially described as a factor stimulating production of granulocyte and/or macrophage colonies, it is now

\section{Received for publication 16 October 1986.}

1. Abbreviations used in this paper: $\mathrm{BFU}-\mathrm{E}$, erythroid burst-forming unit; BPA, burst-promoting activity; CFU-E, erythroid colony-forming unit; CFU-GM, granulocyte-monocyte colony-forming unit; CFU-MIX, erythroid and granulocyte and/or monocyte colony-forming unit; CM, conditioned medium; CSA, colony stimulating activity; EP, erythropoietin; FCS, fetal calf serum; G-CSF, granulocyte colony-stimulating factor; GM-CSF, granulocyte monocyte colony-stimulating factor; IL-1, interleukin 1; M-CSF (CSF-1), macrophage colony-stimulating factor; MIA Paca, human pancreatic tumor cell line; MO-CM, MO T lymphoblast cell line CM; TNF, tumor necrosis factor.

J. Clin. Invest.

(c) The American Society for Clinical Investigation, Inc.

0021-9738/87/06/1549/09 \$1.00

Volume 79, June 1987, 1549-1557 clear that with erythropoietin it also induces the formation of colonies derived from early erythroid burst-forming units (BFUE) and from mixed colony-forming units that comprise granulocytes, erythroid cells, macrophages and megakaryocytes (CFUGEMM or CFU-MIX) (9-14). Although human GM-CSF is clearly therefore a multipoietin, confusion has arisen by introducing new terms to describe the expanded target cell range of this and possibly other factors. Not all of the additional effects of these purified CSFs have been confirmed. The factors themselves and their roles in hematopoiesis have been more clearly established in murine species. Table I lists the murine and human factors, including their nomenclature, major biological activities, homologies, and specificities. Several important points should be noted. Firstly, only very recently has a human homologue for murine multi-CSF (interleukin 3, IL-3), the factor influencing the proliferation of stem cells and committed progenitors of multiple cell lineages, been identified (15). Secondly, the CSFs are produced by multiple cell types. Since indirect effects can be produced by accessory cells present in unfractionated cells that are capable of factor production, investigations of the biological activities of these factors can be influenced by the degree of purity of the target cell population obtained. Thirdly, it is apparent from Table I that several factors have overlapping activities. In comparing the actions of the purified hormones it is important to distinguish effects on self-renewal or survival, proliferation, and differentiation. It has not yet been possible to purify normal hematopoietic target cells in sufficient quantities to determine the intracellular biochemical pathways involved and to distinguish differences in the effects of the various factors on phases of the cell cycle. There is evidence, however, that at least two and possibly three classes of factors may be important for complete cell development in a number of lineages $(16,17)$ : class I factors such as multi-CSF and GM-CSF act on pluripotent cells and immature progenitor cells. They are not lineage specific, are required throughout differentiation, are important for selfrenewal and proliferation of these cells and contribute as well to their differentiation. Class II factors (e.g., G-CSF, M-CSF, and erythropoietin, EP) act on more mature progenitor cells, and are only required later during the development of specific cell lineages. They influence proliferation and differentiation of progenitors, and survival of mature cells. At the present time, there is evidence of a third class: a factor that has synergistic activity with either multi-CSF or M-CSF (18-20), but no colonystimulating activity (CSA) alone. The factor, termed hematopoietin 1 , has been purified from a human bladder carcinoma cell line (19). The combined stimulus of this factor with M-CSF leads to the formation of giant murine macrophage colonies in vitro. The gene for this factor has not been isolated and no analogous human assay for this activity has been described. The biological activities of the five cloned CSFs is presented in Fig. 1 , together with an hypothesis that indicates pathways by which CSF production may be regulated (see below). 
Table I. Murine and Human Hematopoietic Growth Factors: Biological Activities

\begin{tabular}{|c|c|c|c|c|c|c|}
\hline \multicolumn{3}{|l|}{ Murine } & \multirow[b]{2}{*}{ Homology" } & \multicolumn{3}{|l|}{ Human } \\
\hline Factor & Alternative name & Major target cells & & Factor & Alternative name & Major target cell \\
\hline & & & $\%$ & & & \\
\hline $\begin{array}{l}\text { Multi-potential } \\
\text { CSF (multi-CSF) }\end{array}$ & $\begin{array}{l}\text { IL3, BPA, HCGF } \\
\text { PSF } \\
\text { MCGF }\end{array}$ & $\begin{array}{l}\text { CFU-S } \\
\text { CFU-MIX } \\
\text { BFU-E } \\
\text { CFU-GM/G/M } \\
\text { CFU-EO } \\
\text { CFU-Meg } \\
\text { Mast cells }\end{array}$ & 29 & Multi-CSF & IL3 & $\begin{array}{l}\text { CFU-MIX } \\
\text { BFU-E } \\
\text { CFU-GM/G/M } \\
\text { CFU-EO } \\
\text { CFU-Meg }\end{array}$ \\
\hline $\begin{array}{l}\text { Granulocyte-macrophage } \\
\text { CSF (GM-CSF) }\end{array}$ & & $\begin{array}{l}\text { CFU-GM } \\
\text { CFU-MIX* } \\
\text { BFU-E* } \\
\text { CFU-Meg* } \\
\text { CFU-EO* }\end{array}$ & 60 & GM-CSF & $\begin{array}{l}\text { CSF- } \alpha \\
\text { Pluripoietin }\end{array}$ & $\begin{array}{l}\text { CFU-GM } \\
\text { BFU-E } \\
\text { CFU-MIX } \\
\text { CFU-EO } \\
\text { CFU-Meg } \\
\text { Granulocytes } \\
\text { Monocytes } \\
\text { Eosinophils } \\
\text { KGI \& HL60 cell lines }\end{array}$ \\
\hline $\begin{array}{l}\text { Granulocyte CSF } \\
\quad \text { (GCSF) }\end{array}$ & & $\begin{array}{l}\text { CFU-G } \\
\text { CFU-MIX } \\
\text { BFU-E }^{\ddagger} \\
\text { WEHI-3B } \\
\quad \text { cell line }\end{array}$ & $\begin{array}{l}69 \\
\leftarrow \\
\rightarrow\end{array}$ & G-CSF & $\begin{array}{l}\text { CSF- } \beta \\
\text { Pluripoietin }\end{array}$ & $\begin{array}{l}\text { CFU-G } \\
\text { HL60 cell line }\end{array}$ \\
\hline $\begin{array}{l}\text { Macrophage CSF } \\
\quad(\mathrm{M}-\mathrm{CSF})\end{array}$ & CSF-1 & CFU-M & $\begin{array}{l}\text { Yes } \\
\leftarrow\end{array}$ & M-CSF & CSF-1 & $\begin{array}{l}\text { CFU-M } \\
\text { Monocyte and myelo- } \\
\text { monocytic cell lines }\end{array}$ \\
\hline Erythropoietin & & $\begin{array}{l}\text { BFU-E } \\
\text { CFU-E }\end{array}$ & $\begin{array}{l}80 \\
\leftarrow \\
\rightarrow\end{array}$ & EP & & $\begin{array}{l}\text { BFU-E (some) } \\
\text { CFU-E }\end{array}$ \\
\hline
\end{tabular}

* High concentrations required; \# amino acid. ${ }^{\ddagger}$ Initiates but does not sustain proliferation. $\leftarrow$ Human factor active on murine cells; $\rightarrow$ murine factor active on human cells. HCFG, hemopoietic cell growth factor; PSF, persisting cell stimulatory factor; MCGF, mast cell growth factor.

Human hematopoietic growth factors

Multi-CSF. Recently a cDNA clone was isolated from a gibbon $T$ cell line that encodes a novel primate CSF (15). The amino acid sequence of this CSF has significant homology with the sequence of murine IL-3 or multi-CSF. The recombinant protein expressed in monkey COS- 1 cells exhibited a broad distribution of molecular species with apparent size ranging between 20,000 and $26,000 \mathrm{D}$, heterogeneity that is characteristic of small glycoproteins. Preliminary results show that it supports the proliferation of erythroid and myeloid human bone marrow progenitors. The gibbon cDNA was used to isolate the human gene, which also has significant homology with murine IL-3; both genes have five exons of similar size and arrangement, and the coding regions of the human and murine genes are $\sim 45 \%$ homologous. The gene has been localized to chromosome 5 . The protein encoded by the human gene differs in 11 of 152 codons from the gibbon sequence. The sequence divergence between rat, murine, gibbon, and human IL-3 is substantially greater than the divergence observed among the other CSF genes.

\section{$G M-C S F$}

GM-CSF was purified to homogeneity from medium conditioned by the human T-lymphotropic virus II (HTLV II) infected T-lymphoblast cell line Mo (4), and is a glycoprotein with an apparent molecular mass of 22,000 D (Table II). Clones containing cDNAs for GM-CSF were isolated by constructing a cDNA library from Mo cell line RNA in an expression vector, and directly screening transfected monkey COS cells for transient expression of GM-CSF (21). The DNA sequence contains a single open reading frame of 432 nucleotides encoding a 144 amino acid precursor protein. In an analogous fashion to other secreted proteins, 17 amino acids are cleaved from the $\mathrm{NH}_{2}$-terminal sequence to yield a mature protein of 127 amino acids. Restriction enzyme analysis of both Mo-cell line and human liver DNA suggests that there is a single gene encoding GM-CSF (21). A human genomic clone has been isolated from a genomic library; it is composed of four exons and three intervening sequences (21a). It has been localized to chromosome 5q21-32 by somatic cell hybrid analysis and in situ hybridization (22), and is therefore 


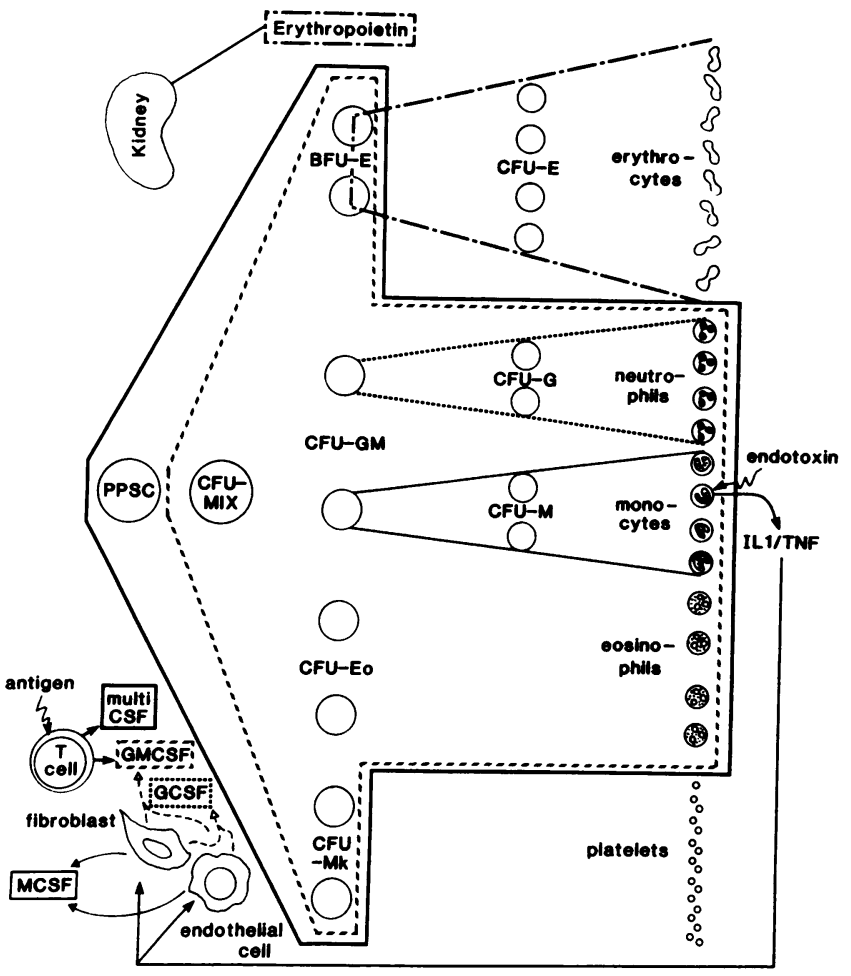

Figure 1. Proposed major spectra of biological activity of the 5 cloned hematopoietic growth factors, indicated by boxes keyed to the different factors. While murine multi-CSF or interleukin 3 affects pluripotent stem cells (PPSC), its human homologue has not been proven to fulfill this role, since assays have not been established. Regulation of hematopoiesis: erythropoietin production by the kidney is determined by tissue oxygen tension; M-CSF and perhaps the other CSFs are produced at low levels by resting stromal cells (fibroblasts and endothelial cells) $(\sim$ ); during infection with microorganisms, endotoxin mediated release of interleukin 1 (IL-1) and/or tumor necrosis factor (TNF) by monocytes greatly increases fibroblast and endothelial cell release of GM-CSF and G-CSF $(\rightarrow)$, and T lymphocyte release of GM-CSF and possibly multi-CSF $(\rightarrow)$; antigen may also directly induce $T$ lymphocyte release of multi-CSF and GM-CSF.

deleted in the $5 \mathrm{q}^{-}$syndrome. Purification of both natural and recombinant human GM-CSF to homogeneity yields identical proteins that are heterogeneous when analyzed by sodium do- decyl sulfate-polyacrylamide gel electrophoresis (SDS-PAGE), migrating with an apparent molecular mass of 14-35,000 D (21). This is most probably due to variable glycosylation; the sequence contains two potential $N$-glycosylation sites. The only significant structural homology so far detected is with the murine GM-CSF, recently cloned from murine lung RNA. The amino acids are $60 \%$ homologous and nucleotide sequences $70 \%$ conserved. Both human and murine GM-CSF contain four cysteine residues, suggesting that disulphide bridges may be structural features of the molecule. Activity is lost on reduction of the molecule. There is no cross-species reactivity (8).

Highly purified natural or recombinant human GM-CSF stimulates granulocyte/macrophage and eosinophil colony formation in vitro. In addition, when partially purified bone marrow progenitor cultures are initiated with GM-CSF, and EP added 3-5 d later, the combined stimulus induces the formation of colonies derived from BFU-E and CFU-MIX as well $(9,11,12)$. In these experiments, purified bone marrow progenitors are plated at low density $(1,000-5,000 / \mathrm{ml})$, and this suggests that GM-CSF can act directly on progenitor cells of all lineages. However, clones initiated in GM-CSF alone and subsequently transferred to either GM-CSF, EP, or GM-CSF + EP have resulted in full maturation of only granulocyte-macrophage and eosinophil colonies (8), supporting the interpretation that GMCSF acts directly on the progenitor cells of the latter lineages. BFU-E were not observed after clonal transfer. One interpretation of this result is that the action of GM-CSF on erythroid progenitors is indirect; alternatively, other factor(s) may be necessary for full erythroid (and multipotent) progenitor differentiation. Support for the latter interpretation comes from the observation that GM-CSF rarely induces as many BFU-E-derived colonies in culture as are formed by optimal concentrations of crude sources of CSA such as Mo cell line CM (9). GM-CSF plateau levels for CFU-GM, eosinophil, and BFU-E colony formation in vitro are $\sim 1-5 \mathrm{ng} / \mathrm{ml}(50-250 \mathrm{pM})$ with half-maximal stimulation observed at 5-50 pM $(8,9)$. The plateau numbers of BFU-E-derived colonies induced by GM-CSF are usually $\sim 2 / 3$ of the number observed with Mo CM. The recent discovery of a human multi-CSF (15) has shown that at least two factors affect the proliferation of early erythroid progenitors. It will be important to determine whether combinations of these two factors and/or other purified factors can act additively or synergistically in these in vitro cultures.

Table II. Recombinant Hematopoietic Growth Factors

\begin{tabular}{|c|c|c|c|c|}
\hline Factor & Source* & Mol mass ${ }^{\ddagger}$ & Gene clone & Ref. \\
\hline Multi-CSF & MLA-144 & $20-26$ & $c D N A:$ 133aa mature protein & 15 \\
\hline GM-CSF & Mo-cell line & $14-35$ & $\begin{array}{l}\text { cDNA: } 127 \text { aa mature protein } \\
\text { genomic clone: } 2.5 \mathrm{~kb}, 4 \text { exons, } 3 \text { introns } \\
\text { chromosome } 5 \mathrm{q} 21-5 \mathrm{q} 32\end{array}$ & $\begin{array}{l}21,10 \\
21 \mathrm{a}, 22\end{array}$ \\
\hline M-CSF & Human urine & 70 dimer & $c D N A:$ 189aa mature protein & 37,36 \\
\hline G-CSF & Human bladder carcinoma & 19.6 & $\begin{array}{l}\text { cDNA: } 177 \text { aa mature protein }(18.7 \mathrm{kD}) \\
\text { genomic clone: } 5 \text { exons, } 4 \text { introns }\end{array}$ & $\begin{array}{l}25,24 \\
26 a\end{array}$ \\
\hline Ep & Human urine & $34-39$ & $\begin{array}{l}c D N A: \text { 166aa mature protein }(18.4 \mathrm{kD}) \\
\text { genomic clone: } 5 \text { exons, single gene }\end{array}$ & 42 \\
\hline
\end{tabular}

\footnotetext{
* Source of purified factor. $\quad$ ॠ Molecular mass of glycosylated protein (kD).
} 
In addition to its effect on progenitor differentiation, GMCSF also induces a variety of functional changes in mature cells. It inhibits polymorphonuclear neutrophil migration under agarose (4) and is a potent activator of neutrophils and eosinophils, inducing antibody dependent cytotoxicity for human target cells $(2,3)$. It increases neutrophil phagocytic activity (8). Some of these functional changes may be related to GM-CSF-induced increase in the cell surface expression of a family of antigens that function as cell adhesion molecules (6). The increase in antigen expression is rapid and associated with increased aggregation of neutrophils: both are maximal at the migration inhibitory concentration of $500 \mathrm{pM}$. The granulocyte-granulocyte adhesion can be inhibited by an antigen-specific monoclonal antibody. A similar pattern of changes was noted when purified monocytes were examined (Bierer, B., and C. Sieff. Unpublished observation.).

\section{Granulocyte colony-stimulating factor ( $G-C S F)$}

Human G-CSF was first purified to apparent homogeneity from medium conditioned by the human bladder carcinoma cell line 5637 (23). It has a molecular mass of $19,600 \mathrm{D}$ and pI 5.5. A human squamous carcinoma cell line (CHU-2) synthesizes large quantities of G-CSF constitutively, and a synthetic oligonucleotide to the determined $\mathrm{NH}_{2}$-terminal amino acid sequence was used to probe cDNA libraries constructed from CHU-2 mRNA (24). A full length cDNA was obtained that codes for a protein of 207 amino acids, of which 177 amino acids comprise mature G-CSF, while 30 hydrophobic amino acids determine the probable leader sequence. The predicted molecular weight of this protein is $\mathbf{1 8 , 9 8 7}$. A similar approach was used to isolate G-CSF cDNA clones from a bladder carcinoma (5637) cDNA library (25). The two clones are identical apart from a deletion of three amino acids at position $36-38$ in the 5637 isolate. Expression of one of these clones in $E$. coli yielded a protein that migrates on SDS-PAGE under reducing conditions with a molecular mass of $18,800 \mathrm{D}$. This agrees with the molecular mass of 18,671 deduced from the amino acid sequence. Recently, Nagata et al. (25a) characterized a DNA fragment containing the G-CSF gene. The gene has five exons and four introns. Two cDNAs that represent the 177 amino acid protein and the 174 amino acid protein with the 36-38 deletion were isolated. Analysis indicated that alternative use of two donor splice sites nine nucleotides apart at the $5^{\prime}$ end of intron 2 is responsible for the production of two different mRNAs for human G-CSF. Both RNAs encode biologically active G-CSF, but differences in bioactivity may exist (25a). It is not known whether two forms of native G-CSF exist in the human. Neuraminidase and $O$-glycanase treatment of natural purified G-CSF (25) reduced the molecular mass of the protein from 19,600 to $18,800 \mathrm{D}$, suggesting that the difference in molecular mass is due to $O$-glycosylation. There are no potential $\mathrm{N}$-glycosylation sites. Southern hybridization of DNA from normal human leukocytes digested with any of four restriction enzymes and probed with a labeled G-CSF cDNA insert showed a single fragment, suggesting that human G-CSF is encoded by a single gene (25).

Initial reports using natural purified human G-CSF or the recombinant hormone suggested that in addition to an effect on granulocyte-macrophage progenitors, G-CSF, in the presence of erythropoietin, induced the formation of colonies derived from BFU-E and CFU-MIX as well (23). In these experiments, the G-CSF was tested on low density bone marrow cells. These results were not confirmed when enriched bone marrow progenitor cells were used instead, and the G-CSF showed a predominant effect on granulocyte progenitors (26 and Sieff, C. A. Unpublished observations.). These data suggest that the reported effects of G-CSF on erythroid and mixed-colony progenitors may be indirect. Murine G-CSF stimulates predominantly granulocyte colony formation from murine bone marrow cells (27), and also has the capacity to induce differentiation of murine myelomonocytic leukemic cell lines such as WEHI-3BD ${ }^{+}(28)$. Partially purified human G-CSF $(29,30)$ has properties analogous to murine G-CSF, and the human and murine G-CSF molecules show almost complete biological and receptor-binding crossreactivities to normal and leukemic murine and human cells (30). Purified murine G-CSF also stimulates antibody dependent cell-mediated cytotoxicity of both murine and human neutrophils (31). The degree of species cross-reactivity exhibited by GCSF is unusual.

\section{$M-C S F$}

Human urinary CSF is a glycoprotein of 47-76,000 D comprising two identical subunits (32). This contrasts with the 70,000-D CSF purified to homogeneity from murine L-cells (33). On reduction the latter species of CSF yields two identical 35,00038,000-D disulphide-bonded subunits (34). The dissociated subunits are not biologically active. Digestion of both human and murine CSF- 1 with endo- $\beta$ - $N$-acetylglucosaminidase $D$ yields a molecule of $16,500 \mathrm{D}$, of which the polypeptide portion accounts for $14,500 \mathrm{D}(35)$. This indicates that the molecule is heavily glycosylated with complex-type N-linked carbohydrate and suggests that variable glycosylation accounts for the difference in molecular weights.

Oligonucleotide probes derived from the amino terminal sequence of human urinary CSF-1 were used to isolate several clones from a human genomic library (36). One of these clones was then used to screen a cDNA library made from 1.5 to $2 \mathrm{~kb}$ mRNA extracted from a phorbol myristic acetate stimulated human pancreatic tumor cell line (MIA Paca). 1 of $10 \mathrm{cDNA}$ clones isolated was transiently expressed in COS 7 cells. The protein was active in murine radioreceptor and bone marrow assays, and was neutralized by an antibody to human urine CSF. Sequence analysis suggested that the gene encodes a protein with a putative leader sequence of 32 amino acids followed by a 224 amino acid mature polypeptide, giving a molecular size of 26,000 $D$, and suggesting that the terminal ends of the primary transcript are processed. Recent data demonstrate that an alternative CSF1 primary transcript that represents the more abundant 4-kb mRNA encodes a 61,000 -D polypeptide that is processed at its amino and carboxy-termini to yield a $21,000-\mathrm{D}$ protein (37). This then undergoes $N$-glycosylation to give a final 35,000-D subunit. COS or CHO cells efficiently process the 61,000-D polypeptide to yield dimeric CSF-1 indistinguishable from natural CSF-1. There is only one gene for CSF-1 (36), and these data therefore indicate that the different RNA species result from differential processing of the primary CSF-1 transcript. These encode at least two different CSF-1 polypeptides that are processed to result in related but different forms of mature CSF-1. The cDNA sequence predicts a hydrophobic region of 23 amino acids that could signify transmembrane insertion (36). This is consistent with studies that suggest that membrane and secretory forms of CSF-1 may exist (38, 38a).

Recombinant or purified human M-CSF induces the for- 
mation of colonies derived predominantly from macrophage progenitors (39), and it is more active on murine than on human target cells. In view of the reported synergism of murine M-CSF with hematopoietin 1, it is possible that human M-CSF requires the presence of another factor(s) for optimal stimulation of human target cells. The effect on human granulocyte macrophage progenitors may be indirect (40). Purified native murine M-CSF increases plasminogen-dependent fibrinolytic activity of mouse peritoneal macrophages (40a).

\section{Erythropoietin}

The EP molecule was first purified to apparent homogeneity from the urine of patients with aplastic anemia (41). EP purified from similar sources was microsequenced and oligonucleotide probes were prepared and used to isolate clones from a human genomic DNA library (42). A probe prepared from the genomic clone was used to isolate cDNA clones from a fetal liver cDNA library. The EP coding information is contained in 579 nucleotides and encodes a 27 amino acid hydrophobic leader sequence followed by the 166 amino acid mature protein. The $\mathrm{N}$-terminus of the mature protein was located by comparison with the sequence of purified human urinary EP originally determined by Goldwasser (43). After transfection of the gene in COS cells, EP activity is detectable in the culture supernatant. The molecular mass of natural EP is 34,000-39,000 D and the deduced molecular mass of the recombinant polypeptide backbone is 18,400 ; the difference in molecular mass is due to glycosylation. There are three sites of $\mathrm{N}$-linked glycosylation at amino acids 24,38 , and 83 and the molecule is also $O$-glycosylated. There are four cysteine residues, and at least two must be involved in disulphide bonds since biological activity is lost on reduction. Only a single gene has been detected, and complete sequence analysis indicates that the mRNA is encoded by five exons. The gene has been localized to chromosome 7q11-q22 by analysis of somatic cell hybrids and by in situ hybridization (43a). Recombinant EP (44), like the natural hormone $(45,46)$, primarily stimulates the proliferation and terminal maturation of CFU-E and a subset of presumptive mature BFU-E. These progenitors do not require burst-promoting activity (BPA) and respond to EP when it is added to cultures on day 0 . If EP addition is delayed until day 3 , even in the presence of BPA, this population either dies or becomes unresponsive to the hormone. A second subset of BFU$\mathrm{E}$, presumably less mature, survive EP deprivation if BPA is present, either as crude conditioned medium (CM) such as Mo cell line CM or as GM-CSF. When EP is added to the cultures on day 3 , these BFU-E proliferate and terminally differentiate to form typical bursts (44).

\section{Membrane receptors for hematopoietic growth factors}

Membrane receptors for all four murine hematopoietic growth factors have been characterized using iodinated purified or recombinant preparations (47-56). The data are summarized in Table III. Consistent with the lack of structural homology among the growth factors is the existence of distinct receptors for each factor. Distribution of receptors is restricted to undifferentiated and maturing cells of the appropriate target cell lineages. Since granulocytes and macrophages respond to more than one factor, overlap in receptor expression occurs. The number of multiCSF (IL-3), GM-CSF, and G-CSF receptors per cell is strikingly low, while those for M-CSF are higher, and in all cases affinity of receptor for ligand is high $\left(10^{9}-10^{12} \mathrm{M}^{-1}\right.$ range). Stimulation of target cells can occur at concentrations of factor orders of magnitude lower than the equilibrium constant at which $50 \%$ of receptors are occupied, and therefore it is apparent that low receptor occupancy is sufficient to produce biological effects. The interaction of M-CSF with its receptor on bone marrow macrophages has been studied and shows that at $37^{\circ} \mathrm{C}$, these cells internalize labeled CSF (57). Although the four murine CSFs do not cross compete for binding at $0^{\circ} \mathrm{C}$, at $21^{\circ}$ or $37^{\circ} \mathrm{C}$, multi-CSF (IL-3) inhibits binding of the other three CSFs, and GM-CSF inhibits binding of G-CSF and M-CSF to bone marrow cells (58). Metcalf has suggested that this hierarchical down modulation results in activation of the modulated receptor, and the model provides an intriguing explanation for the correlation between the pattern of down regulation and the biological activity of the different murine CSFs.

Little published information exists concerning human growth factor receptors $(59,60)$. Low numbers of GM-CSF receptors are expressed by mature polymorphonuclear neutrophils and by the myeloid leukemic cell lines KG1 and HL60. Reported affinity constants range from $10^{9}$ to $10^{12} \mathrm{M}^{-1}$ and only one class of binding sites has been reported, in contrast to one of the murine GM-CSF binding studies in which both high and low affinity classes of receptors were reported (49).

Recent evidence (61) suggests strongly that the M-CSF receptor and the protooncogene product c-fms are closely related and possibly identical proteins: both proteins are of similar size $(165,000 \mathrm{D})$ and exhibit tyrosine kinase activity; an antibody to c-fms precipitates a protein that is phosphorylated on tyrosine in the presence of purified M-CSF, and ${ }^{125}$ I M-CSF can be recovered from immunoprecipitates of receptor-membrane extracts. These data are of considerable interest and provide new evidence linking oncogenes and growth factors: v-erb B encodes a protein that is a truncated form of the epidermal growth factor receptor (62), and c-sis codes for a polypeptide chain of platelet

Table III. Receptors for Murine Hematopoietic Growth Factors

\begin{tabular}{lllll}
\hline & Mol mass & Sites/cell & $K_{\mathrm{d}}$ & Ref. \\
\hline & $(k D)$ & & $M /$ liter & 47 \\
Multi-CSF & - & $1000-5000$ & $2-5 \times 10^{-11}$ & 48 \\
GM-CSF & 72.5 & 430 & $7 \times 10^{-9}$ & 49 \\
G-CSF & 50 & $1000-5000$ & $10^{-9}-10^{-8}$ & 50 \\
M-CSF & $130-180$ & $50-500$ & $6-8 \times 10^{-11}$ & 51,52 \\
\end{tabular}

* Two classes of receptor reported, high/low affinity. 
derived growth factor (63). v-fms is the oncogene of the McDonough strain of feline sarcoma virus, and expression at the cell surface is required for transformation (64). The virus was first isolated from a feline fibrosarcoma (65), and fibroblast cell lines are transformed with the highest efficiency (61). It has not been implicated in hematopoietic neoplasms. Since fibroblasts secrete M-CSF (66), and the v-fms product appears to contain an almost complete extracellular domain, it is possible that transformation of fibroblasts depends on ligand binding and transduction of a signal through a functional receptor in a cell that does not normally require M-CSF for growth. However, simian virus 40 immortalized, CSF-1 dependent macrophages do not secrete or express CSF-1. They can be rendered CSF-1 independent after introduction of the $v$-fms gene (66a). The carboxyl terminal end of $\mathrm{v}$-fms differs from $\mathrm{c}$-fms in that $\mathbf{4 0}$ amino acids of $\mathrm{c}-\mathrm{fms}$ are replaced by 11 unrelated residues in the vfms product (66b). This change results in constitutive autophosphorylation of the v-fms protein, in contrast to the c-fms product in which autophosphorylation is enhanced by CSF-1. This suggests that the factor independence induced by $v$-fms expression in macrophages is due to unregulated kinase activity that provides growth stimulation in the absence of ligand.

\section{Cellular sources and regulation of production of the CSFs}

While all murine tissues contain extractable hematopoietic growth factors, it is likely that synthesis of the four major CSFs is restricted to cells common to all organs: fibroblasts, endothelial cells, lymphocytes, and macrophages (reference 1 for review). Similarly, many human organs are capable of synthesizing CSFs and bioactivity assays on medium conditioned by purified cell populations have likewise documented CSF production by $\mathrm{T}$ lymphocytes (67-69), monocytes (70-73), endothelial cells (7476), and fibroblasts (77). Two points are worth noting: the bioactivity experiments do not clearly distinguish the factors from each other because of overlapping spectra of activity, and these cell types are more easily purified than many tissue constituents; an answer to the question of whether other cells synthesize growth factors therefore will depend on use of in situ RNA hybridization techniques with radioactive probes to the different factors. RNA extracted from purified cell populations can be assayed by the Northern technique. Phytohemagglutinin-stimulated blood mononuclear cells (comprising monocytes and lymphocytes) contain GM-CSF mRNA. Furthermore, this source of RNA and certain $\mathrm{T}$-cell lines are to date the only cells that are positive with a probe to the recently isolated human multi-CSF cDNA (see Fig. 1) (Clark, S. C. Personal communication.). Recently, we and others have probed endothelial $(78,78 \mathrm{a}, 78 \mathrm{~b})$, fibroblast (78b) and monocyte RNA with labeled cDNAs to all four CSFs (Sieff, C. A., and C. Niemeyer. Unpublished observations.). While uninduced cells of all three types appear to contain $\mathrm{M}$ CSF RNA, primary umbilical vein endothelial cells $(78,78 \mathrm{a}$, $78 \mathrm{~b}$ ) and lung (78b), skin, and fetal liver fibroblasts only synthesize detectable GM-CSF RNA after induction with IL-1 and/ or tumor necrosis factor. Monocyte synthesis of G-CSF appears to depend on induction with endotoxin. Since monocytes produce IL-1 in response to endotoxin (79), this cell may perform a central role in inducing increased hematopoiesis during stress, both by producing growth factors, but perhaps more importantly by producing IL-1 and TNF. These monokines may induce circulating T-lymphocytes to produce both GM-CSF and multi-
CSF. Removal of T-lymphocytes from bone marrow before allogeneic bone marrow transplantation in order to prevent graft versus host disease therefore could be depleting the marrow of a cell critical for proliferation of the transplanted pluripotent stem cells. Monocyte-derived IL-1 and/or TNF may also induce fixed bone marrow stromal (endothelial [78] and fibroblast [80, 80a]) cell populations to produce GM-CSF and G-CSF as well. This is consistent with published evidence demonstrating the ability of monokines present in monocyte conditioned medium to induce endothelial $(81,82)$, fibroblast (83) and T-lymphocyte (84) production of BPA and CSA. Basal hematopoiesis, on the other hand, is probably maintained by local production of CSFs by fixed stromal cells (endothelial, fibroblast and perhaps macrophages).

\section{In vivo effects and prospects for therapy}

Cloning of the GM-CSF gene and production of the recombinant hormone in large quantities have provided the impetus for intensive investigation of its in vivo actions, in order to identify clinical circumstances in which it may be useful. In preliminary in vitro experiments it was found that simian bone marrow progenitors respond to human recombinant GM-CSF in vitro (85). The clearance of metabolically labeled ${ }^{35} \mathrm{~S}$ GM-CSF injected into monkeys is multiphasic, with an initial decay of radioactivity of half-life seven minutes and a second component of half-life 80-90 min. Continuous intravenous infusion of GM-CSF into seven normal macaques dramatically increased the leukocyte count, which reached a level seven times above the preinfusion average, was observed within one to three days of the start of the infusion, and was maintained by continuous infusion in one animal for $28 \mathrm{~d}$ (85). Neutrophils, band neutrophils, eosinophils, monocytes, lymphocytes, and reticulocytes increased concomitantly, whereas infusion of a control solution had no effect. A similar response was also demonstrated by administering the protein by subcutaneous infusion to a severely debilitated pancytopenic rhesus monkey that had been naturally infected with a simian type D retrovirus (85). Recently, encouraging results have been obtained in a simian bone marrow transplant model (Donahue, R. E., and A. Nienhuis. Personal communication.). Thus, GM-CSF appears to be a potent stimulator of normal primate hematopoiesis, and may also stimulate hematopoiesis in certain hypoplastic states.

Recently, preliminary results have been reported on the in vivo effects of G-CSF in primates $(86,87)$. It is active in normal monkeys and causes a dose-dependent increase in neutrophils. It also may shorten the period of neutropenia after sublethal chemotherapy or after lethal total body irradiation followed by autologous bone marrow transplantation.

Phase I/II trials of recombinant erythropoietin for the treatment of patients with end-stage renal disease have been completed. The results are extremely encouraging, and indicate that a rise in hematocrit can be achieved and continuously maintained, with elimination of the blood transfusion requirement $(88,89)$.

\section{Future directions}

Cloning of the genes for the hematopoietic growth factors and production of quantities of purified recombinant protein have, as discussed above, helped clarify some previously controversial areas. Furthermore, several new lines of research will now be 
possible, both in understanding the cell biology of production and interaction of growth factors with their target cells, and in evaluating their potential therapeutic role.

Thus, it will be important to identify the producer cells in the bone marrow microenvironment and their relationship to developing progenitors by using in situ RNA hybridization techniques. Very little is known about the mechanism by which the growth factors induce cell proliferation and differentiation; one hopes that the receptors for all the human growth factors will soon be identified, and their mechanism of activating cells and relationship, if any, to known cellular oncogenes investigated. The majority of myeloid leukemic blasts that are capable of colony formation in culture are dependent on the addition of exogenous CSFs present in conditioned media for proliferation in vitro (90). In most cases GM-CSF can substitute for some, but not all, sources of conditioned media. GM-CSF appears to be one, but not the only factor capable of stimulating leukemic cell proliferation, and it will be important to identify other factors capable of fulfilling this role. Only a proportion of myeloid leukemic cells appear capable of "autonomous" proliferation in vitro, and therefore the simple model of factor secretion and autostimulation by leukemic blasts appears unlikely to be an important mechanism in the emergence of a leukemic clone. However, a surprising number of acute myeloid leukemic blasts contain GM-CSF mRNA, and a proportion of these secrete CSF as well (90a). A defect leading to uncoupling of ligand-receptor mediated proliferation with differentiation is likely to exist, but in some cases, expression of CSF genes by leukemic cells could promote the expansion of leukemic clones in vivo. A detailed comparison of receptor number and function in normal and leukemic cells is at present difficult because of the inability to obtain large numbers of purified normal progenitors, although progress in this area is encouraging (12).

Finally, it will be important to establish the therapeutic roles, if any, for GM-CSF, erythropoietin, and the other growth factors as they become available in large quantities. GM-CSF may be useful in shortening the period of aplasia associated with ablative chemoradiotherapy for bone marrow transplantation, and could stimulate hematopoiesis in some patients with hypoplastic bone marrows. G-CSF may be useful as a stimulus of granulopoiesis in infected patients. In addition, since it has been shown to be capable of inducing the differentiation of leukemic blasts (91), it will be evaluated for a therapeutic role in this disease. Erythropoietin is presently being tested as treatment for anemia uremic patients; the results are extremely promising, and trials are being planned to evaluate the hormone in other anemias.

The advances in molecular biology that have led to the production of both highly purified CSF recombinant gene products and specific probes for their presence in tissues have revolutionized experimental hematology. During the next few years, these tools should provide the opportunity for investigators to answer many of the intriguing questions in relation to CSF production, mechanism of action in normal and leukemic cells, and the therapeutic role in patients suffering from defects of production of blood cells.

\section{Acknowledgments}

The author would like to thank David Nathan and Steven Clark for helpful comments.
This research was supported by grants from the National Institutes of Health and the Dyson Foundation.

\section{References}

1. Metcalf, D. 1984. The Hemopoietic Growth Factors. Elsevier, Amsterdam.

2. Vadas, M. A., N. A. Nicola, and D. Metcalf. 1983. J. Immunol. 130:795-799.

3. Vadas, M. A., G. Varigos, N. Nicola, S. Pincus, A. Dessein, D. Metcalf, and F. L. Battye. 1983. Blood. 61:1232.

4. Gasson, J. C., R. H. Weisbart, S. E. Kaufman, S. C. Clark, R. M. Hewick, G. G. Wong, and D. W. Golde. 1984. Science (Wash. DC). 226: 1339-1342.

5. Weisbart, R. H., D. W. Golde, S. C. Clark, G. G. Wong, and J. C. Gasson. 1985. Nature (Lond.). 314:361-363.

6. Arnaout, M. A., E. A. Wang, S. C. Clark, and C. A. Sieff. 1986. J. Clin. Invest. 78:597-601.

7. Grabstein, K. H., D. Urdal, R. J. Tushinski, D. Y. Mochizuki, V. L. Price, M. A. Cantrell, S. Gillis, and P. J. Conlon. 1986. Science (Wash. DC). 232:506-508.

8. Metcalf, D., C. G. Begley, G. R. Johnson, N. A. Nicola, M. A. Vadas, A. F. Lopez, D. G. Williamson, G. G. Wong, S. C. Clark, and E. A. Wang. 1986. Blood. 67:37-45.

9. Sieff, C. A., S. G. Emerson, R. E. Donahue, D. G. Nathan, E. A. Wang, G. G. Wong, and S. C. Clark. 1985. Science (Wash. DC). 230: 1171-1173.

10. Kaushansky, K., P. O'Hara, K. Berkner, G. M. Segal, V. Broudy, F. Hagen, and J. W. Adamson. 1985. Blood. 66(Suppl. 1):153a, 500. (Abstr.)

11. Donahue, R. E., S. G. Emerson, E. A. Wang, G. G. Wong, S. C. Clark, and D. G. Nathan. 1985. Blood. 66:1479-1481.

12. Emerson, S. G., C. A. Sieff, E. A. Wang, G. G. Wong, S. C. Clark, and D. G. Nathan. 1985. J. Clin. Invest. 76:1286-1290.

13. Gabrilove, J. L., K. Welte, P. Harris, E. Plotzer, L. Lee, E. Levi, R. Mertelsmann, and M. A. S. Moore. 1986. Proc. Natl. Acad. Sci. USA. 83:2478-2482.

14. Tomonaga, M., D. W. Golde, and J. C. Gasson. 1986. Blood. 67:31-36.

15. Yu-Chung Yang, A. B. Ciarletta, P. A. Temple, M. Chung, S. Kovacic, J. S. Witek-Giannotti, A. C. Leary, R. Kriz, R. E. Donahue, G. G. Wong, and S. C. Clark. 1986. Cell. 47:3-10.

16. Stanley, E. R., and P. T. Jubinsky. 1984. Clin. Haematol. 13: 329-336.

17. Iscove, N. N. 1978. In Haematopoietic Cell Differentiation (ICN UCLA Symposia on Molecular and Cellular Biology Vol. 10). D. W. Golde, M. J. Cline, D. Metcalf, and F. C. Fox, editors. Academic Press, New York.

18. Bartelmez, S. H., and E. R. Stanley. 1985. J. Cell. Physiol. 122: 370-378.

19. Jubinsky, P. T., and E. R. Stanley. 1985. Proc. Natl. Acad. Sci. USA. 82:2764-2768.

20. Stanley, E. R., A. Bartocci, D. Patinkin, M. Rosendaal, and T. R. Bradley. 1986. Cell. 45:667-674.

21. Wong, G. G., J. S. Witek, P. A. Temple, K. M. Wilkens, A. C. Leary, D. P. Luxenberg, S. S. Jones, E. L. Brown, R. M. Kay, E. C. Orr, C. Shoemaker, D. W. Golde, R. J. Kaufman, R. M. Hewick, E. A. Wang, and S. C. Clark. 1985. Science (Wash. DC). 228:810-815.

21a. Miyatake, S., T. Otsuka, T. Yokota, F. Lee, and K. Arci. 1985. EMBO J. 4:2561-2568.

22. Huebner, K., M. Isobe, C. M. Croce, D. W. Golde, S. E. Kaufman, and J. C. Gasson. 1985. Science (Wash. DC). 230:1282-1285.

23. Welte, K., E. Platzer, L. Lu, J. L. Gabrilove, E. Levi, R. Mertelsmann, and M. A. S. Moore. 1985. Proc. Natl. Acad. Sci. USA. 82: $1526-1530$.

24. Nagata, S., M. Tsuchiya, S. Asano, Y. Kaziro, T. Yamazaki, O. 
Yamamoto, Y. Hirata, N. Kubota, M. Oheda, H. Nomura, and M. Ono. 1986. Nature (Lond.). 319:415-418.

25. Souza, L. M., T. C. Boone, J. Gabrilove, P. H. Lai, K. M. Zsabo, D. C. Murdock, V. R. Chazin, J. Bruszewski, H. Lu, K. K. Chen, J. Barendt, E. Platzer, M. A. S. Moore, R. Mertelsmann, and K. Welte. 1986. Science (Wash. DC). 232:61-65.

25a. Nagata, S., M. Tsuchiya, S. Asano, O. Yamamoto, Y. Hirata, N. Kubota, M. Oheda, H. Nomura, and T. Yamazaki. 1986. EMBO (Eur. Mol. Biol. Organ) J. 5:575-581.

26. Strife, A., C. Lambek, D. Wisniewski, S. Gulati, J. Gasson, D. Golde, K. Welte, J. Gabrilove, and B. Clarkson. 1987. Blood. 69:15081523.

27. Metcalf, D., and N. A. Nicola. 1983. J. Cell. Physiol. 116:198206.

28. Nicola, N. A., D. Metcalf, M. Matsumoto, and G. R. Johnson. 1983. J. Biol. Chem. 258:9017-9023.

29. Nicola, N. A., D. Metcalf, G. R. Johnson, and A. W. Burgess. 1979. Blood. 54:614-627.

30. Nicola, N. A., C. G. Begley, and D. Metcalf. 1985. Nature (Lond.). 314:625-628.

31. Lopez, A. F., N. A. Nicola, A. W. Burgess, D. Metcalf, F. L. Battye, W. A. Sewell, and M. Vadas. 1983. J. Immunol. 131:2983-2988.

32. Stanley, E. R., G. Hansen, J. Woodcock, and D. Metcalf. 1975. Fed. Proc. 34:2272-2278.

33. Stanley, E. R., and P. M. Heard. 1977. J. Biol. Chem. 252:43054312.

34. Das, S. K., E. R. Stanley, L. J. Guilbert, and L. W. Forman. 1981. Blood: 58:630-641.

35. Das, S. K., and E. R. Stanley. 1982. J. Biol. Chem. 257:1367913684.

36. Kawasaki, E. S., M. B. Ladner, A. M. Wang, J. Van Arsdell, M. K. Warren, M. Y. Coyne, V. L. Schweickart, M. T. Lee, K. J. Wilson, A. Boosman, E. R. Stanley, P. Ralph, and D. F. Mark. 1985. Science (Wash. DC). 230:291-296.

37. Wong, G. G., P. A. Temple, A. C. Leary, J. S. Witek-Giannotti, Y.-C. Yang, A. B. Ciarletta, M. Chung, P. Murtha, R. Kriz, R. J. Kaufman, C. R. Ferenz, B. S. Sibley, K. J. Turner, R. M. Hewick, S. C. Clark, N. Yanai, H. Yokota, M. Yamada, M. Saito, K. Motoyoshi, and S. Takaku. 1987. Science (Wash. DC). 235:1504-1509.

38. Cifone, M., and V. Defendi. 1974. Nature (Lond.). 252:151-152.

38a. Stanley, E. R., M. Cifone, P. M. Heard, and V. Defendi. 1976. J. Exp. Med. 143:631-647.

39. Stanley, R. E., and L. J. Guilbert. 1980. In Mononuclear Phagocytes-Functional Aspects, Part I. van Furth, R., editor. The Hague, Netherlands.

40. Motoyoshi, K., F. Takaku, H. Mizoguchi, and Y. Miura. 1978. Blood. 52:1012-1020.

40a. Hamilton, J. A., E. R. Stanley, A. W. Burgess, and R. K. Shadduck. 1980. J. Cell. Physiol. 103:435-445.

41. Miyake, T., C. K.-H. Kung, and E. Goldwasser. 1977. J. Biol. Chem. 252:5558-5564.

42. Jacobs, K., C. Shoemaker, R. Rudersdorf, S. D. Neill, R. J. Kaufman, A. Mufson, J. Seehra, S. J. Jones, R. Hewick, E. F. Fritsch, M. Kawakita, T. Shimizu, and T. Miyake. 1985. Nature (Lond.). 313:806810.

43. Lai, P.-H., R. Everett, F.-F. Wang, T. Arakawa, and E. Goldwasser. 1986. J. Biol. Chem. 261:3116-3121.

43a. Law, M. L., G.-Y. Cai, F.-K. Lin, A. Wei, S.-Z. Huang, J.-H. Hartz, H. Morse, C.-H. Lin, C. Jones, and F.-T. Kao. 1986. Proc. Natl. Acad. Sci. USA. 83:6920-6924.

44. Sieff, C. A., S. G. Emerson, A. Mufson, T. G. Gesner, and D. G. Nathan. 1986. J. Clin. Invest. 77:74-81.

45. Eaves, C. J., and A. C. Eaves. 1978. Blood. 52:1196-1210. 391.

46. Eaves, A. C., and C. J. Eaves. 1984. Clin. Haematol. 13:371-

47. Palaszynski, E. W., and J. N. Ihle. 1984. J. Immunol. 132:18721878.
48. Park, L. W., D. Friend, S. Gillis, and D. L. Urdal. 1986. J. Biol. Chem. 261:205-210.

49. Walker, F., and A. W. Burgess. 1985. EMBO (Eur. Mol. Biol. Organ.) J. 4:933-939.

50. Park, L. S., D. Friend, S. Gillis, and D. L. Urdal. 1986. J. Biol. Chem. 261:4177-4183.

51. Nicola, N. A., and D. Metcalf. 1985. J. Cell. Physiol. 124:313321.

52. Nicola, N. A., and D. Metcalf. 1984. Proc. Natl. Acad. Sci. USA. 81:3765-3769.

53. Guilbert, L. J., and E. R. Stanley. 1980. J. Cell Biol. 85:153159.

54. Morgan, C. J., and E. R. Stanley. 1984. Biochem. Biophys. Res. Commun. 119:35-41.

55. Byrne, P. V., L. J. Guilbert, and E. R. Stanley. 1981. J. Cell Biol. $91: 848-853$.

56. Shadduck, R. K., G. Pigoli, C. Caramatti, G. Degliontoni, V. Rizzoli, A. Porcellini, A. Waheed, and L. Schiffer. 1983. Blood. 62:11971202.

57. Guilbert, L. J., and L. J. Stanley. 1986. J. Biol. Chem. 261:40244032.

58. Walker, F., N. A. Nicola, D. Metcalf, and A. W. Burgess. 1985. Cell. 43:269-276.

59. Gasson, J. C., S. E. Kaufman, R. H. Weisbart, M. Tomonaga, and D. W. Golde. 1986. Proc. Natl. Acad. Sci. USA. 83:669-673.

60. Park, L. S., D. Friend, S. Gillis, and D. L. Urdal. 1986. J. Exp. Med. 164:251-262.

61. Sherr, C. J., C. W. Rettenmier, R. Sacca, M. F. Roussel, A. T. Look, and E. R. Stanley. 1985. Cell. 41:665-676.

62. Downward, J., Y. Yarden, E. Maeys, G. Scrace, N. Totty, P. Stockwell, A. Ullrich, J. Schlessinger, and M. D. Waterfield. 1984. Nature (Lond.). 307:521-527.

63. Waterfield, M. D., G. T. Scrace, N. Whittle, P. Stroobant, A. Johnsson, A. Wasteson, B. Westermark, C.-H. Heldin, J. S. Huang, and T. F. Deuel. 1983. Nature (Lond.). 304:35-39.

64. Roussel, M. F., C. W. Rettenmier, A. T. Look, and C. J. Sherr. 1984. Mol. Cell. Biol. 4:1999-2009.

65. McDonough, S. K., S. Larsen, R. S. Brodey, N. D. Stock, and W. D. J. Hardy. 1971. Cancer Res. 31:953-956.

66. Tushinski, R. J., I. T. Oliver, L. J. Guilbert, P. W. Tynan, J. R. Warner, and E. R. Stanley. 1982. Cell. 28:71-81.

66a. Wheeler, E. F., C. W. Rettenmier, A. T. Look, and C. J. Sherr. 1986. Nature (Lond.). 324:377-380.

66b. Coussens, L., C. Van Beveren, D. Smith, E. Chen, R. L. Mitchell, C. M. Isacke, I. M. Verma, and A. Ullrich. 1986. Nature (Lond.). 320: 277-280.

67. Cline, M. J., and D. W. Golde. 1974. Nature (Lond.). 248:703704.

68. Nathan, D. G., L. Chess, D. G. Hillman, B. Clarke, J. Breard, J. Merler, D. E. Housman. 1978. J. Exp. Med. 147:324-339.

69. Mangan, K. F., G. Chikkappa, L. Z. Sieler, W. B. Scharfman, and D. R. Parkingson. 1982. Blood. 59:990-996.

70. Chervenick, P. A., and A. F. LoBuglio. 1972. Science (Wash. DC). 178:164-166.

71. Golde, D. W., and M. J. Cline. 1972. J. Clin. Invest. 51:2981.

72. Zuckerman, K. S. 1981. J. Clin. Invest. 67:702-709.

73. Reid, C. P. L., L. C. Batista, and I. Chanarin. 1981. Br. J. Haematol. 48:155-164.

74. Knudson, S., and B. T. Mortenson. 1975. Blood. 46:937-943.

75. Quesenberry, P. J., and M. A. Gimbrone. 1980. Blood. 56:10601067.

76. Ascencao, J. L., G. M. Vercellotti, H. S. Jacob, and E. D. Zanjani. 1984. Blood. 63:553-558.

77. Tsai, S., S. G. Emerson, C. A. Sieff, and D. G. Nathan. 1986. J. Cell. Physiol. 127:137-145.

78. Sieff, C. A., S. Tsai, and D. V. Faller. 1987. J. Clin. Invest. 79: 48-51. 
78a. Broudy, V. C., K. Kaushansky, G. M. Segal, J. M. Harlan, and J. W. Adamson. 1986. Proc. Natl. Acad. Sci. USA. 83:7467-7471.

78b. Munker, R., J. Gasson, M. Ogawa, and H. P. Koeffler. 1986. Nature (Lond.). 328:79-82.

79. Dinarello, C. A. 1984. N. Engl. J. Med. 311:1413-1418.

80. Sieff, C. A., C. Niemeyer, S. Tsai, S. C. Clark, and D. V. Faller. 1986. Blood. 68(Suppl. 1):180a.

80a. Zucali, J. R., C. A. Dinarello, D. J. Oblon, M. A. Gross, L. Anderson, and R. S. Weiner. 1986. J. Clin. Invest. 77:1857-1863.

81. Bagby, G. C., E. McCall, K. A. Bergstrom, and D. Burger. 1983. Blood. 62:663-668.

82. Zuckerman, K. S., G. C. Bagby, E. McCall, B. Sparks, J. Wells, V. Patel, and D. Goodrum. 1985. J. Clin. Invest. 75:722-725.

83. Bagby, G. C., E. McCall, and D. L. Layman. 1983. J. Clin. Invest. 71:340-344.

84. Bagby, G. C., V. D. Rigas, R. M. Bennett, A. A. Vandenbark, and H. S. Garewal. 1981. J. Clin. Invest. 68:56-63.

85. Donahue, R. E., E. A. Wang, S. Stone, R. Kamen, G. S. Wong,
D. G. Sehgal, D. G. Nathan, and S. C. Clark. 1986. Nature (Lond.). 321: 872-875.

86. Welte, K., M. A. Bonilla, A. P. Gillio, T. Boone, G. K. Potter, J. Gabrilove, M. A. S. Moore, R. J. O'Reilly, and L. Souza. 1987. J. Exp. Med. In press.

87. Gillio, A. P., M. A. Bonilla, R. J. O'Reilly, G. K. Potter, T. Boone, L. Souza, and K. Welte. 1986. Blood. 68:(Suppl. 1), 283a, abstr. 1009.

88. Winearls, C. G., D. O. Oliver, M. J. Pippard, C. Reid, M. R. Downing, and P. M. Cotes. 1986. Lancet. ii:1175-1178.

89. Eschbach, J. W., J. C. Egrie, M. R. Downing, J. K. Browne, and J. W. Adamson. 1987. N. Engl. J. Med. 316:73-78.

90. Griffin, J. D., D. Young, F. Herrman, D. Wiper, K. Wagner, and K. D. Sabbath. 1986. Blood. 67:1448-1453.

90a. Young, D. C., K. Wagner, and J. D. Griffin. 1987. J. Clin. Invest. 79:100-106.

91. Nicola, N. A., C. G. Begley, and D. Metcalf. 1985. Nature (Lond.). 314:625-628. 